\title{
Taking Stock: What Do We Know, and Do not Know, about the National Treatment Obligation in the GATT/WTO Legal System?
}

\author{
Ming Du \\ Reader in Law, Lancaster University Law School \\ Michael.mingdu@gmail.com
}

\begin{abstract}
Even though widely recognized as one of the core disciplines of international economic law, the interpretation of national treatment ("NT") obligation has been long marked by legal indeterminacy. More recently, a series of landmark cases, including Us-Clove Cigarettes, Us - Tuna II (Mexico), Us - COOL and EC-Seal Products, have fundamentally reshaped our collective understanding of the NT obligation in the GATT/WTO system. The objective of this article is to take stock of what we have already known about the NT obligation in the wTO law, identify the lingering uncertainties and discuss the options for the WTO Appellate Body to bring more clarity to the NT obligation in future dispute settlements.
\end{abstract}

\section{Keywords}

National treatment - GATT 1994 - твT Agreement - WTO

It is conventional wisdom that one fundamental tension in the world trading system is the need to strike a delicate balance between the pursuit of trade liberalization and member states' right to regulate. ${ }^{1}$ In different World

1 John H. Jackson, World Trade and the Law of GATT (Indianapolis: The Bobbs-Merrill Company, 1969), at 788. As to why this tension is fundamental to the legitimacy of the WTO 
Trade Organization ("WTо") Agreements, this balance is expressed in different ways. As to the domestic non-fiscal regulation of goods, for example, this balance is expressed by the national treatment ("NT") obligation embodied in Article III:4 as qualified by the exceptions in Article XX of the General Agreement on Tariffs and Trade (GATT). Compared to GATT Article III:4, there are at least two textual differences in the NT obligation embodied in Article 2.1 of the Agreement on Technical Barriers to Trade ("т вт Agreement"). The first difference is that Article 2.1 does not have an umbrella provision similar to Article III: of the GATT; the second difference is that the твт Agreement does not contain a general exception clause similar to Article XX of the GATT. Then, how do these textual differences inform the interpretation of NT obligation in the твт Agreement? Should Article 2.1 of the твт Agreement have identical interpretation as Article III:4 of the GATT?

Moreover, even though widely recognized as one of the pillars of the GATT/ WTO system, the interpretation of the NT obligation has been long marked by legal indeterminacy. ${ }^{2}$ One prominent WTO scholar once lamented: "After all these years, we are still in the dark as to the precise ambit of what has been time and again described as the "cornerstone" of the GATT edifice." ${ }^{3}$ For the first time in the Wто history, the wто Appellate Body ("АВ") explored and clarified the nature and scope of the NT obligation in Article 2.1 of the тв T Agreement in the recent three твт cases: Us-Clove Cigarettes, Us - Tuna II (Mexico) and US - COOL. ${ }^{4}$ The innovative твт jurisprudence has in turn spurred much spec-

regime, see Ming Du, The Rise of National Regulatory Autonomy in the GATT/WTo Regime, 14 Journal of International Economic Law 3 (2011), at 641-654.

2 Nicolas F. Diebold, Standards of Non-Discrimination in International Economic Law, 60 International and Comparative Law Quarterly (2011), at 832-833. Tomer Broude and Philip I. Levy, Do you Mind if I do not Smoke? Products, Purpose and Indeterminacy in Us-Measures Affecting the Production and Sale of Clove Cigarettes, 13 World Trade Review 2 (2014), at 368. Simon Lester, Finding the Boundaries of International Economic Law, 17 Journal of International Economic Law 1 (2014), at 9.

3 Petros C. Mavroidis, Come Together? Producer Welfare, Consumer Welfare, and WTo Rules, in Ernst-Ulrich Petersmann (ed.) Reforming the World Trading System: Legitimacy, Efficiency, and Democratic Governance (Oxford: Oxford University Press, 2005), at 284.

4 Wто Appellate Body Report, United States-Clove Cigarettes, WT/DS406/AB/R, adopted 24 April 2012, AB-2012-1; WTO Appellate Body Report, United States-Measures Concerning the Importation, Marketing and Sale of Tuna and Tuna Products, WT/DS381/AB/R, adopted 13 June 2012, AB-2012-2; WTO Appellate Body Report, United States-Certain Country of Origin Labelling (COOL) Requirements, WT/DS384/AB/R, adopted 23 July 2012, AB-2012-3. For an overview of the three cases, see Gabrielle Marceau, The New твт Jurisprudence in UsClove Cigarettes, US-Tuna II, and US-COOL, 8 Asian Journal of WTO and International Health Law and Policy 1 (2014), at 1-39. For a more critical analysis, see Petros C. Mavroidis, 
ulation about to what extent the $\mathrm{AB}$ may transpose its new approach to the NT obligation in Article 2.1 of the твт Agreement to Article III:4 of the Gatт. ${ }^{5}$ The speculation is now over after the $\mathrm{AB}$ issued its landmark $E C$-Seal Products ruling in June 2014. ${ }^{6}$

The objective of this article is to take stock of what we have already known about the NT obligation in the GATT/WTO system, identify the lingering uncertainties and discuss how the Wто Panels and the Aв may bring more clarity to this core legal principle after $E C$-Seal Products in future dispute settlements. The paper is organized as follows. Section two reviews the WTO AB's evolving interpretation of the NT obligation in Article III:4 of the GATT 1994 before EC-Seal Products. Section three examines critically how the Aв dealt with the NT obligation in Article 2.1 of the твт Agreement in the three recent твт disputes. Section four introduces the most recent $E c$-Seal Products case and reflects on how the Ав has reshaped our collective understanding of the NT obligation in Article III:4 of the GATT 1994. Also explored in part four are some of the remaining uncertainties to be clarified in future dispute settlements. Section five concludes the article.

\section{The NT Obligation in Article III:4 of the GATT 1994 before Ec-Seal Products}

With regard to the domestic non-fiscal regulation of goods, the NT obligation is contained in Article III:4 of the GATT 1994. Article III:4 provides:

The products of... any contracting party imported into ... any other contracting party shall be accorded treatment no less favorable than that accorded to like products of national origin in respect of all laws, regulations and requirements...

Driftin' Too Far from Shore - Why the Test for Compliance with the твт Agreement Developed by the WTO Appellate Body is Wrong, and what should the AB have Done Instead, 12 World Trade Review 3 (2013), at 509-31.

5 James Flett, wTO Space for National Regulation: Requiem for a Diagonal Vector Test, 16 Journal of International Economic Law 1 (2013), at 73-76; Weihuan Zhou, us-Clove Cigarettes and US-Tuna II (Mexico): Implications for the Role of Regulatory Purpose under Article III:4 of the GATT, 15 Journal of International Economic Law 4 (2012), at 1110-22.

6 wто Appellate Body Report, European Communities-Measures Prohibiting the Importation and Marketing of Seal Products (EC-Seal Products), wT/DS400/AB/R, adopted on 18 June 2014. 
The essence of Article III:4 is that imported products must be offered "treatment no less favorable" than that accorded to domestic like products. In addition, Article III:4 should be read in light of Article III:1, which serves as a guiding principle of the whole Article III. ${ }^{7}$ Article III:1 reads:

The Members recognize that... internal laws, regulations and requirements... should not be applied to imported or domestic products so as to afford protection to domestic production.

As will be discussed below, the interpretation of key terms of the NT obligation, such as "like products" and "treatment no less favorable" is not an easy exercise. ${ }^{8}$ In particular, what has persistently puzzled wTO scholars is how exactly Article III:1 shall inform the interpretation of "like products" and "treatment no less favorable" in Article III:4. ${ }^{9}$ Should a panel consider the regulatory purpose of a measure when determining whether or not there is a violation of the NT obligation? If yes, where should this consideration take place, in "like products" analysis, in "treatment no less favorable" analysis or in a separate and additional step after the "like products" and "treatment no less favorable treatment" analyses? To what extent could the consideration of Article III:1 render a measure with detrimental impact on imported products nevertheless consistent with Article III:4?

\section{1 "Like Products"}

In $E C$-Asbestos, the AB found that the determination of "like products" under Article III:4 is fundamentally a determination of the nature and extent of a competitive relationship between and among products. ${ }^{10}$ In assessing this competitive relationship, the $\mathrm{AB}$ usually examines (i) properties, nature and quality of products; (ii) the extent to which products are capable of serving the same or similar uses; (iii) the extent to which consumers perceive and treat the products as alternative means of performing particular functions in order

$7 \quad$ WTo Appellate Body Report, European Communities-Measures Affecting Asbestos and Asbestos-Containing Products (EC-Asbestos), WT/DS135/AB/R, adopted 5 April 2001, para. 93 .

8 Nicolas DiMascio and Joost Pauwelyn, Nondiscrimination in Trade and Investment Treaties: Worlds apart or Two Sides of the Same Coin, 102 American Journal of International Law (2008), at 62-66.

9 Weihuan Zhou, The Role of Regulatory Purpose under Article III:2 and 4-Toward Consistency between Negotiating History and WTO Jurisprudence, 11 World Trade Review 1 (2012), at $84-87$.

$10 \quad$ WTo Appellate Body Report, EC —Asbestos, para. 99. 
to satisfy a particular want or demand; and (iv) the international classification of the products for tariff purposes. ${ }^{11}$ All other evidence revealing the competitive relationship between products should also be considered. ${ }^{12}$ Ever since $E C$-Asbestos, the AB has taken the stance that a thorough examination of the competitive relationship between the two products in the marketplace, mainly through the traditional four-factor analysis, is sufficient to decide whether they are "like products". Even if regulatory purpose in Article III:1 needs to be considered when interpreting the NT obligation in Article III:4, it should not be considered as part of the "like products" inquiry.

However, this market- based "like products" test has been heavily criticized for technical, structural and normative reasons over the years. In $E C-$ Asbestos, the Ав pondered the technical difficulties in interpreting "like products" under Article III:4:

First, the dictionary definition of "like" does not indicate which characteristics or qualities are important in assessing the "likeness" of products under Article III:4, since most products will have many qualities and characteristics... Second, it provides no guidance in determining the degree or extent to which products must share quality or characteristics... as products may share only a few characteristics or qualities, or they may share many...Third, it does not indicate from whose perspective "likeness" should be judged. Ultimate consumers may have a view about "likeness" of two products that is very different from that of producers of those products. ${ }^{13}$ (emphasis added)

Structurally, if a domestic regulatory measure is found to discriminate against imports in violation of Article III, the regulating government can seek to justify that discrimination by proving that it is "necessary" or "related to" the achievement of some legitimate regulatory purposes enshrined in Article Xx of the GATT 1994. However, this is not a desirable route as Article XX was traditionally interpreted stringently. ${ }^{14}$ In addition, Article Xx provides a closed list of

11 Ibid., para. 101.

12 Ibid., para. 103.

13 Ibid., para. 92; Robert E. Hudec, GATT/WTo Constraints on National Regulation: Requiem for an "Aim and Effects" Test, 32 International Lawyer (1998), at 626.

14 Gisele Kapterian, A Critique of the wTo Jurisprudence on Necessary, 59 International and Comparative Law Quarterly (2010), at 97. Sanford E. Gaines, The WTO's Reading of the GATT Article XX Chapeau: A Disguised Restriction on Environmental Measures, 22 University of Pennsylvania Journal of International Law (2001), at 739-862; Donald M. McRae, GATT 
legitimate objectives for government intervention. It is doubtful whether this closed list written sixty years ago is adequate to justify all legitimate government intervention in the 21st century.

Normatively, the market-based "like products" test raises a deeper and troubling issue of the very symbolism of political identity, the way a society wants to understand its internal hierarchy of values. In this regard, the market-based test establishes a normative hierarchy whereby the default norm is liberalized trade, and for competing values, such as human health and safety and protection of the environment, to prevail, they have to be justified..$^{15}$

Such concerns gave rise to an alternative approach to "like products" analysis, generally known as the "aims and effects" test, in the GATT case law in the early 1990s. The aims and effects test can be viewed as an effort to relax the stark dichotomy of Article III and Article xx, especially with regard to origin-neutral regulatory measures. According to this test, "like products" are not defined by reference to prevailing perceptions about the pair of products in the market place, but by reference to the regulatory aim pursued by the intervening government. ${ }^{16}$

In 'aims and effects' test, the panel inferred from the text of Article III:1 that the purpose of Article III is not to prevent contracting parties from using their fiscal and regulatory powers by differentiating between different product categories for policy purposes unrelated to the protection of domestic protection. The panel considered that this limited purpose of Article III had to be taken into account in interpreting the term "like products". In the panel's view, the determination of the relevant features common to the domestic and imported products had to include an examination of the aims and effects of the particular measure:

A measure could be said to have the aim of affording protection if an analysis of the circumstances demonstrated that a change in competitive opportunities in favor of domestic products was a desired outcome

Article XX and the WTO Appellate Body, in Marco Bronckers and Reinhard Quick (eds.), New Directions of International Economic Law, (The Hague: Kluwer International, 2000), at 226 .

15 Henrik Horn and J.H.H. Weiler, Ec-Asbestos, in Henrik Horn and Petros C. Mavroidis (eds.), The WTO Case Law of 2001 (Cambridge: Cambridge University Press 2003), at 31.

16 GatT Panel Report, United States-Measures Affecting Alcoholic and Malt Beverages (US-Malt Beverages), DS23/R, adopted 19 June 1992, BISD 39S/206; GATT Panel Report, United States - Taxes on Automobiles (Us - Taxes on Automobiles), DS31/R, 11 October 1994, unadopted. 
and not merely an incidental consequence of the pursuit of a legitimate policy goal. A measure could be said to have the effect of affording protection to domestic production if it accorded greater competitive opportunities to domestic products than to imported products. ${ }^{17}$

Although the aims and effects test has much to be commended, certain problems mitigated against its application. The panel report of Japan-Alcoholic Beverages II explained these problems in the context of Article III:2 and the same reasons also apply to Article III:4. ${ }^{18}$ To begin with, similar to Article III:2 the first sentence, Article III:4 contains no textual reference to Article III:1. Second, the adoption of the aims and effects approach has important repercussions for the burden of proof imposed on the complainant in the dispute settlement processes. Under such an approach, the complainant would bear the burden of showing not only discriminatory effects, but also that the aim of the measure is to afford protection to domestic production. However, the aim of a measure may be sometimes indiscernible. In the case of a multiplicity of aims, it would be a difficult exercise to determine which aim or aims should be determinative for applying the test. Finally, the aims and effects test may render Article XX virtually redundant. If panels were required to consider the regulatory purpose of a measure when deciding violation under Article III, all regulatory justifications provided in Article xx would have already been considered in the first stage determination of violation, leaving no reason to conduct the same inquiry again under Article $\mathrm{xx} .{ }^{19}$ By contrast, the traditional objective "like products" test does not involve any subjective value judgments. Arguably, this protects the panel and the $\mathrm{AB}$ and may increase the perception of legitimacy of the $\mathrm{AB}$ rulings. ${ }^{20}$ Because of these defects and legitimacy concerns, the $\mathrm{AB}$ rejected the aims and effects test inJapan-Alcoholic Beverages II shortly after the establishment of the WTO in 1995 .

\section{2 "Treatment No Less Favorable"}

The panel in US - Section 337 Tariff Act (1989) stated, "The words 'treatment no less favorable' calls for effective equality of opportunities for imported products in respect of the application of laws, regulations and requirements

\footnotetext{
17 Ibid., Us - Taxes on Automobiles, para. 5.10.

18 WTo Panel Report, Japan-Taxes on Alcoholic Beverages (Japan-Alcoholic Beverages), WT/Ds8/R, adopted 1 November 1996, as modified by wTO Appellate Body Report WT/ $\mathrm{DS} 8 / \mathrm{AB} / \mathrm{R}$, paras. $6.16-6.18$.

19 Ibid.

$20 \quad$ Horn and Weiler, Ec-Asbestos, at 30-31.
} 
compared to the domestic products". ${ }^{21}$ In other words, the "treatment no less favorable" standard prohibits wто Members from modifying the conditions of competition in the market place to the detriment of imported products vis-à-vis domestic like products. ${ }^{22}$

Previously the AB's interpretation of "like products" received by far the most attention. More recently, the focus has shifted to "treatment no less favorable". 23 In Korea-Beef (2001), the Ав made it clear that a formal difference in treatment between imported and like domestic products, even if based exclusively on the origin of the products, is neither necessary, nor sufficient, to show a violation of Article III:4. Rather, what is relevant is whether such regulatory differences modified the conditions of competition to the detriment of imported products. ${ }^{24}$ In addition, the less favorable treatment, i.e., negative economic effects, must affect the group of imported products, as compared to the group of domestic products. In other words, the NT obligation will be breached only if imported products, on the whole, are treated less favorably than domestic products. It is not enough that one imported product is or may be treated less favorably than one domestic like product. ${ }^{25}$

Similar to the interpretation of "like products", there has been a long-term debate on how should Article III:1 inform the interpretation of "treatment no less favorable". In $E C$-Bananas III, the AB concluded that, as there is no specific reference to Article III:1 in Article III:4, there is no requirement to determine separately whether a measure is applied "so as to afford protection to domestic production". ${ }^{26}$ In $E c$-Asbestos, the AB stated that Article III:1

21 GATt Panel Report, United States Section 337 of the Tariff Act of 1930, L/6439, adopted 7 November 1989, BISD 36S/345, para. 5.11.

22 Peter Van den Bossche and Werner Zdouc, The Law and Policy of the World Trade Organization (Cambridge: Cambridge University Press, 3rd ed. 2013), at 396.

23 Joost Pauwelyn, The Unbearable Lightness of Likeness, in Marion Panizzon, Nicole Pohl and Pierre Sauve (eds.), GATS and the Regulation of International Trade in Services (Cambridge: Cambridge University Press 2008), at 366-67; Lothar Ehring, De Facto Discrimination in World Trade Law: National and Most-Favored-Nation Treatment- or Equal Treatment? 36 Journal of World Trade 5 (2002), at 944.

24 Wто Appellate Body Report, Korea-Measures Affecting Imports of Fresh, Chilled and Frozen Beef, wT/DS161/AB/R, adopted 10 January 2001, paras. 137-44.

25 wTo Appellate Body Report, Ec-Asbestos, para. 100; Ehring, De Facto Discrimination, at 925 .

26 Wто Appellate Body Report, European Communities-Regime for the Importation, Sale and Distribution of Bananas (EC-Bananas III), WT/DS27/AB/R, adopted 25 September 1997, para. 216. 
"informs" Article III:4 and should act as a guide to understanding and interpreting Article III:4. ${ }^{27}$ The AB states:

The term "less favorable treatment" expresses the general principle in Article III:1: if there is "less favorable treatment" of the group of like imported products, there is, conversely, "protection" of the group of "like" domestic products. However, a Member may draw distinctions between products which have been found to be "like", without, for this reason alone, according to the group of "like" imported products less favorable treatment than that accorded to the group of "like" domestic products. $^{28}$

Here the Ав explicitly recognized that Article III:1 "informs" Article III:4. Recall that the "like products" inquiry does not consider the regulatory purpose of the measure, the $\mathrm{AB}$ seemed to indicate that the regulatory purpose might be considered when determining whether foreign products are accorded "treatment less favorable" than domestic "like products". It is also clear from the paragraph quoted above that there is no separate and additional inquiry on the regulatory purpose of the measure under Article III:1.

However, the $\mathrm{AB}$ did not make it clear how the regulatory purpose might inform "less favorable treatment" in $E c$-Asbestos. ${ }^{29}$ Will a finding of disparate impact to the detriment of imported products automatically lead to "less favorable treatment", and thus a violation of the NT obligation? If not, should the consideration of regulatory purpose be part of the "less favorable treatment" analysis? What could the AB possibly have in mind when they use the tantalizing phrase whereby "a Member may draw distinctions between 'like' products" without resulting in less favorable treatment? Is it because the purpose of the distinction is not trade protectionism?

As some prominent wTO commentators speculated, the ambiguous statement that a Member may draw distinctions between "like products" without resulting in less favorable treatment could certainly be a platform from which to embrace an intent analysis, reviving to some extent the aims and effects test. ${ }^{30}$

\footnotetext{
27 WTo Appellate Body Report, EC —Asbestos, para. 93.

28 Ibid., para. 100.

29 Donald Regan, Regulatory Purpose and "Like Products" in Article III:4 of the GATT, in Bermann \& Mavroidis (eds.), Trade and Human Health and Safety (Cambridge: Cambridge University Press 2006), at 214.

$30 \quad$ Henrik Horm and Joseph H.H. Weiler, European Communities-Measuring Affecting Asbestos and Asbestos-Containing Products, 3 World Trade Review 1, (2004), at 147; Amelia
} 
However, it was later clarified in Thailand-Cigarettes that in EC-Asbestos, the Ав did not mean that the panel should try to explore the regulatory purpose of a disputed measure, nor may a non-protectionist explanation render an otherwise discriminatory measure consistent with the NT obligation. The correct understanding of the quoted paragraph above is that it restates what the AB stated in Korea-Beef, i.e., a formal regulatory distinction itself is not conclusive evidence of less favorable treatment. Rather, the investigative focus should be whether conditions for competition between and among like products were modified to the detriment of imported products. ${ }^{31}$

On the critical question of whether a finding of detrimental impact on imported products vis-à-vis domestic like products, without more, is sufficient to conclude a violation of the NT obligation under Article III:4, the AB report of Dominican Republic - Cigarettes caused even more confusion. In this case, Honduras argued that Dominican Republic's requirement that importers and domestic producers post a bond of $\mathrm{RD} \$ 5$ million to ensure payment of taxes has a detrimental impact on the class of imported cigarettes compared with the class of domestic cigarettes. In the view of the $A B$, this detrimental effect on imported cigarettes was not enough to find a violation of the NT obligation:

$[\mathrm{T}]$ he existence of a detrimental effect on a given imported product resulting from a measure does not necessarily imply that this measure accords less favorable treatment to imports if the detrimental effect is explained by factors or circumstances unrelated to the foreign origin of the product... ${ }^{32}$ (emphasis added)

After Dominican Republic-Cigarettes, almost all panels and WTO experts understood the $\mathrm{AB}$ as saying that it is not sufficient to find inconsistency with Article III:4 solely on the basis that the measure at issue modifies the conditions of competition to the disadvantage of imported products. The complainant must also show that those adverse effects are related to the foreign origin of the products. In other words, a non-protectionist explanation, that is, an explanation unrelated to the foreign origin of the product, may be evidence

Porges and Joel P. Trachman, Robert Hudec and Domestic Regulation: The Resurrection of Aim and Effects, 37 Journal of World Trade 4 (2003), at 796-97.

31 WTo Appellate Body Report, Thailand -Customs and Fiscal Measures on Cigarettes from the Philippines (Thailand -Cigarettes), wT/DS371/AB/R, adopted 15 July 2011, para. 128. wто Appellate Body Report, Dominican Republic -Measures Affecting the Importation and Internal Sale of Cigarettes (Dominican Republic_Cigarettes), WT/DS302/AB/R, adopted 19 May 2005, para. 96. 
that there is no less favorable treatment to imports. ${ }^{33}$ In $E C$ - Biotech Products, Argentina, the Us, and Canada complained that the EC had accorded less favorable treatment to biotech products than to non-biotech products, despite the fact that they are "like products". The Panel stated:

Argentina is not alleging that the treatment of products has differed depending on their origin. In these circumstances, it is not self-evident that the alleged less favorable treatment of imported biotech products is explained by the foreign origin of these products rather than, for instance, a perceived difference between biotech products and non-biotech products in terms of their safety, etc. In our view, Argentina has not adduced argument and evidence sufficient to raise a presumption that the alleged less favorable treatment is explained by the foreign origin of the relevant biotech products. ${ }^{34}$ (emphasis added)

In US - Tuna II, the panel found that Mexico had failed to demonstrate that the us "dolphin-safe" labelling provisions afford less favorable treatment to Mexican tuna products. The panel reasoned:

The impact of the us dolphin-safe provisions on different operators on the market and on tuna products of various origins depends on a number of factors that are not related to the nationality of the product, but to the fishing and purchasing practices, geographical location, relative integration of different segments of production, and economic and marketing choices. ${ }^{35}$

Clearly, in these cases, the panels interpreted the Ав report of Dominican Republic-Cigarettes as requiring a separate and additional step of inquiring whether the detrimental effect is explained by factors or circumstances unrelated to the foreign origin of the product, before any conclusion on "treatment no less favorable" may be drawn.

33 DiMascio and Pauwelyn, Nondiscrimination in Trade and Investment Treaties, at 64-65; Du, National Regulatory Autonomy, at 659-64; Zhou, Towards Consistency, at 106-12.

34 Wто Panel Report, European Communities-Measures Affecting the Approval and Marketing of Biotech Products, WT/DS291/R, adopted 21 November 2006, para. 7.2514.

wто Panel Report, United States-Measures Concerning the Importation, Marketing and Sale of Tuna and Tuna Products (US - Tuna II), WT/Ds381/R, adopted 13 June 2012, as modified by the Appellate Body report, para. 7.378. 
In Us-Clove Cigarettes, the $\mathrm{AB}$ refuted this popular understanding. In footnote 372 of the report, the $\mathrm{AB}$ clarified that there is no additional inquiry of whether the detrimental impact was related to the foreign origin of the products or whether there are any non-protectionist policy justifications for such a disparate impact under Article III:4. The intriguing statement in the AB report of Dominican Republic-Cigarettes simply stresses the fact that the sales of domestic cigarettes are greater than those of imported cigarettes on the Dominican Republic market. Consequently, per unit cost of the bond requirement for imported cigarettes is higher than domestic products. ${ }^{36}$ In other words, the higher per unit costs of the bond requirement for imported cigarettes was not attributable to the specific measure at issue but was a function of sales volumes. ${ }^{37}$ It is now clear that what the AB meant to establish in Dominican Republic - Cigarettes was a test of "causation" under which a panel needs to consider whether any alleged disparate impact is caused by a challenged measure. ${ }^{38}$ If some other factors, rather than the disputed measure, are accountable to the disparate impact, then the measure in dispute has not modified conditions of competition, hence no "treatment less favorable".

In Thailand-Cigarettes, the $\mathrm{AB}$ has provided more guidance on how to approach "treatment no less favorable" in Article III.4. First, the AB stated that the analysis of the implications of the contested measure for the equality of competitive conditions must begin with careful scrutiny of the measure, including consideration of the design, structure, and expected operation of the measure. ${ }^{39}$ Such an analysis may involve, but need not be based on, the actual effects of the contested measure in the market place, nor should the Panel anchor the analysis of less favorable treatment in an assessment of the degree of likelihood that an adverse impact on competitive conditions will materialize. ${ }^{40}$ Second, if the regulation at issue indicates an origin-based, de jure discrimination, i.e., the sole difference in regulatory treatment consists of requirements applied only to imported products; there is a significant indication that imported products are accorded less favorable treatment. ${ }^{41}$ In Thailand-Cigarettes, Thailand exempted three sets of VATrelated administrative requirements for resellers of domestic cigarettes, but imposed these administrative requirements on resellers of imported cigarettes.

\footnotetext{
$36 \quad$ wто Appellate Body Report, Dominican Republic_Cigarettes, para. 96.

37 Ibid., footnote 372.

38 Zhou, Regulatory Purpose, at 1115.

39 WTо Appellate Body Report, Thailand -Cigarettes, paras. 130 and 134.

40 Ibid.

41 Ibid., para. 133.
} 
Without much difficulty, the $\mathrm{AB}$ ruled that less favorable treatment could be established. ${ }^{42}$ Finally, in any event, there must be in every case a genuine relationship between the measure at issue and its adverse impact on competitive opportunities for imported versus domestic like products. ${ }^{43}$

Article 2.1 of the твт Agreement provides:

Members shall ensure that in respect of technical regulations, products imported from the territory of any Member shall be accorded treatment no less favourable than that accorded to like products of national origin and to like products originating in any other country.

According to the $\mathrm{AB}$, for a violation of the NT obligation in Article 2.1 to be established, three elements must be satisfied: (i) technical regulation, (ii) like products, and (iii) no less favorable treatment. ${ }^{44}$ For the purpose of this article, only the last two elements will be discussed.

\section{1 "Like products"}

In US-Clove Cigarettes, the panel questioned the conventional wisdom of interpreting like products primarily from a competition-oriented perspective. On top of the traditional four factors, the panel attempted to add an additional consideration, the regulatory purpose of the legitimate objective pursued. ${ }^{45}$ The panel held that the determination of like products in Article 2.1 should be influenced by the fact that the measure in question is a technical regulation having the immediate purpose of regulating cigarettes for public health reasons. ${ }^{46}$ In essence, the panel attempted to revive at least part of the aims and effects test in determining like products under the твт Agreement.

The $\mathrm{AB}$ unequivocally rejected such an attempt for two reasons. First, measures often pursue a multiplicity of objectives. It would not always be possible for a panel to identify all the objectives and be in a position to determine which objectives are relevant to the determination of like products. If a panel were to

\footnotetext{
42 Ibid., paras. 139-140.

43 Ibid.

44 wто Appellate Body Report, us - Clove Cigarettes, para. 87.

45 Marceau, New твт Jurisprudence, at 7.

46 WTo Appellate Body Report, us_Clove Cigarettes, para. 107.
} 
focus only on one of the multiple objectives, it may reach a somewhat arbitrary result in the determination of what are the "like products" at issue. ${ }^{47}$ Second, the concept of like products serve to define the scope of products that should be compared to establish whether less favorable treatment is being accorded to imported products. If products that are in a sufficiently strong competitive relationship to be considered like are excluded from the group of like products on the basis of a measure's regulatory purpose, this would inevitably distort the less favorable treatment comparison. ${ }^{48}$

After US-Clove Cigarettes, it is settled that the determination of "like products" under Article 2.1 of the твт Agreement adopts the same competitionoriented approach as Article III:4 of the GATT 1994. It is a determination about the nature and extent of a competitive relationship between and among products at issue..$^{49}$ In such a determination, a panel should discount any distortive effects that the measure at issue may itself have on the competitive relationship, and reserve the consideration of such effects for the analysis of "less favorable treatment"..$^{0}$ Similarly, a panel should not consider the regulatory purpose of the measures in question when determining "like products". ${ }^{51}$ In this connection, a distinction should be drawn between the regulatory purpose of the measures and the regulatory concerns underlying the measure. While the regulatory purpose should not be considered in determining "like products", the regulatory concerns may play a role in the determination of likeness to the extent that they are relevant to the examination of certain likeness criteria and are reflected in the competitive relationship between and among the products concerned. ${ }^{52}$ In $E C$-Asbestos, for example, the health risks associated with chrysotile asbestos are considered relevant in determining whether chrysotile asbestos and PCG fibres are like products. This is because health risks affect physical properties as well as consumer tastes and preferences..$^{53}$

\section{2 "Treatment no less favorable"}

The interpretation of "treatment no less favorable" is a tricky one in the твт Agreement. The твт Agreement does not contain a "general exceptions" clause similar to Article XX of the GATT 1994. If "treatment no less favorable"

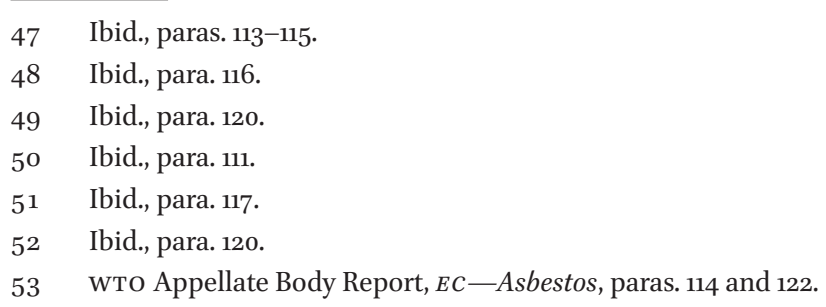


were interpreted in the same way as Article III:4, any technical regulation having a detrimental impact on the group of imported products vis-à-vis the group of domestic like products would violate Article 2.1 of the твт Agreement. This will be the case even if the technical regulation in question has a legitimate regulatory objective and is executed even-handedly. Clearly, this is not an acceptable outcome, as it would prioritize trade liberalization with no regard to other non-economic social values.

In US-Clove Cigarettes, the AB first argues that the purpose of Article 2.1 is not to prohibit a priori any obstacles to international trade. Instead, a WTO Member has the right to pursue legitimate regulatory objectives. The AB points to the sixth recital of the preamble of the твт Agreement to support this interpretation. The sixth recital expressly acknowledges that Members' right to regulate should not be constrained if the measures taken are necessary to fulfill certain legitimate policy objectives, and provided that they are not applied in a manner that would constitute a means of arbitrary or unjustifiable discrimination or a disguised restriction on international trade. ${ }^{54}$

After Us-Clove Cigarettes, it is settled that a finding of "treatment no less favorable" under Article 2.1 of the твт Agreement requires a two-step analysis. First, a panel must find that the measure at issue modifies the conditions of competition in the relevant market to the detriment of the group of imported products vis-à-vis the group of domestic like products. The existence of such a detrimental effect however is not sufficient to demonstrate less favorable treatment under Article 2.1. In the second step, a panel must further analyze whether the detrimental impact on imports stems exclusively from a legitimate regulatory distinction. ${ }^{55}$ If a regulatory distinction is not designed and applied in an even-handed manner because, for example, it is designed or applied in a manner that constitutes a means of arbitrary or unjustifiable discrimination, that distinction cannot be considered "legitimate". ${ }^{56}$ In assessing even-handedness, a panel must scrutinize the design, architecture, revealing structure, operation, and application of the technical regulation at issue. ${ }^{57}$

In Us-Clove Cigarettes, because clove cigarettes and menthol cigarettes are "like products" and that clove cigarettes are banned while menthol cigarettes are permitted in the Us, there was little difficulty for the $\mathrm{AB}$ to conclude that such differential treatment is to the detriment of the imported products.

54 WTo Appellate Body Report, us - Clove Cigarettes, para. 95.

55 Ibid., para. 182.

56 wто Appellate Body Report, us — Cool, para. 271.

57 Wто Appellate Body Report, us - Clove Cigarettes, para. 182; wTо Appellate Body Report, us-Tuna II, WT/Ds381/AB/R, paras. 231-32. 
In the second step, the $\mathrm{AB}$ found that the cigarettes that are prohibited by the us measure consist primarily of clove cigarettes imported from Indonesia. By contrast, the "like products" that are actually permitted consisted primarily of us domestically produced menthol cigarettes, accounting for about $26 \%$ of the total us cigarette market. ${ }^{58}$ This strongly suggests that the detrimental impact on competitive opportunities for clove cigarettes imported from Indonesia reflects discrimination. Moreover, the $\mathrm{AB}$ found that the reasons presented by the Us for the exemption of menthol cigarettes from the ban do not demonstrate that the detrimental impact on imported clove cigarettes stems from a legitimate regulatory distinction. The us argued that the exemption of menthol cigarettes from the ban is necessary because of the potential impact of a menthol ban on us health care system due to withdrawal treatment, and the potential development of a black market. The AB found that us arguments do not really stick because it is not clear if these risks would materialize if menthol cigarettes were to be banned, insofar as regular cigarettes would remain in the market. ${ }^{59}$

In US - Tuna II, Mexico challenged a US measure that monitored and enforced the "dolphin-safe" label on tuna. The AB found that the "dolphin-safe" label has significant commercial value for tuna products on the us market. The us measure prohibited the use of the label on tuna marketed in the us in any instance where the tuna was caught by a method involving encircling or setting upon dolphins. Because Mexican vessels usually catch tuna by setting on dolphins in the Eastern Tropical Pacific (ETP), most tuna caught by Mexican vessels would not be eligible for the label. By comparison, most tuna from the us and other countries that are sold in the us market were caught by other fishing methods outside the ETP. Therefore, most tuna caught by us vessels are eligible for a "dolphin-safe" label. The lack of access to the "dolphin-safe" label has a detrimental impact on the competitive opportunities of Mexican tuna products in the us market. ${ }^{60}$ Further, the $\mathrm{AB}$ concluded that the detrimental impact of the us labelling requirement did not stem exclusively from a legitimate regulatory distinction. Under the us measure, tuna harvested in the ETP may be labelled "dolphin-safe" if the captain and an observer certify that no dolphins were killed or seriously injured and that there was no setting on dolphins during the same fishing trip. ${ }^{61}$ However, the us measure does not address mortality (observed or unobserved) arising from fishing methods

\footnotetext{
58 Ibid., Us - Clove Cigarettes, paras. 223-24.

59 Ibid., para. 225 .

6o WTo Appellate Body Report, Us - Tuna II, paras. 235-40.

61 Ibid., para. 176.
} 
other than setting on dolphins outside the EтP. As a result, the tuna caught in a non-ETP fishery would be eligible for the us "dolphin-safe" label even if dolphins had in fact been killed or seriously injured during the fishing trip. ${ }^{62}$ The evidence shows that the us labelling requirements are not calibrated to the risks to dolphins arising from different fishing methods in different areas of the ocean, and less favorable treatment was afforded to imported Mexican tuna. The $\mathrm{AB}$ believed that it is feasible for the us to address the deficiency of the labelling requirements. ${ }^{63}$

In US-Cool, the Us government imposed on retailers an obligation to provide Us country of origin labelling (COOL) information on a range of meat products. In examining various possible methods of compliance with the $\mathrm{COOL}$ measure, the $\mathrm{AB}$ found that the design of the COOL measure and its operations within the us market, particularly the recordkeeping and verification requirements, meant that the least costly way is to rely exclusively on domestic livestock. ${ }^{64}$ In addition, the costs of compliance cannot fully be passed on to consumers. The AB then concluded that the COOL measure creates an incentive for us market participants to process exclusively domestic livestock and reduce the competitive opportunities of imported livestock. ${ }^{65}$

The COOL measure thus modifies the conditions of competition in the us market to the detriment of imported livestock. The $\mathrm{AB}$ then proceeded to consider whether the regulatory distinctions, i.e., different labels to reflect the different production steps of birth, raising and slaughter, embodied in the COOL measure are designed and applied in an even-handed manner. Looking at the design and application of the COOL measure, the $\mathrm{AB}$ found that the recordkeeping and verification requirements in the COOL measure impose a disproportionate burden on upstream producers and processors. ${ }^{66}$ This disproportionality cannot be explained by the need to convey to consumers through labels information on country of origin because the COOL measure as applied is unlikely to be successful in conveying accurate information to consumers for a number of reasons. First, the level of information conveyed to consumers through the mandatory labelling requirements is far less detailed and accurate than the information required to be tracked and transmitted by these producers and processors. As a result, consumers are not able to comprehend the meaning of the labelling programmer accurately. Second, some

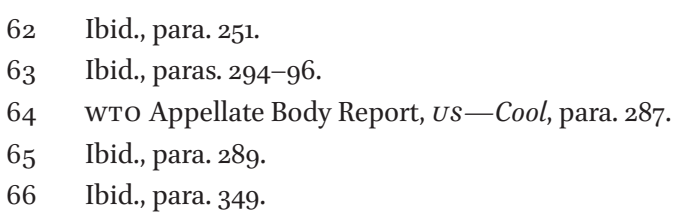


labels lead to confusing or inaccurate origin information conveyed to consumers. Third, upstream producers may be subject to the COOL measure's onerous recordkeeping and verification requirements even when the meat is ultimately exempt from the labelling requirements altogether. ${ }^{67}$ The $\mathrm{AB}$ concluded that the regulatory distinctions imposed by the COOL measure amount to arbitrary and unjustifiable discrimination against imported livestock, such that they cannot be said to be applied in an even-handed manner.

It is immediately clear that the first step in the AB's "treatment no less favorable" analysis mirrors much of Article III:4 case law. Moreover, the second step in the AB's "treatment no less favorable" analysis resembles the chapeau test of Article XX of the GATT $1994 .{ }^{68}$ This is not a surprise because the sixth recital of the preamble of the твт Agreement closely mirrors the chapeau. The chapeau of Article xx sets forth a non-discrimination requirement that prohibits a measure from being "applied in a manner which would constitute a means of arbitrary or unjustifiable discrimination between countries where the same conditions prevail". In Brazil—Retreaded Tyres, the Aв held that the determination of "arbitrary or unjustifiable discrimination" is essentially an analysis that relates primarily to the cause or the rationale of the discrimination put forward to explain its existence. ${ }^{69}$ As the AB stated:

There is arbitrary or unjustifiable discrimination... when the reasons given for this discrimination bear no rational connection to the objective falling within the purview of a paragraph of Article xx, or would go against that objective. ${ }^{70}$

After Brazil—Retreaded Tyres, it is settled that the determination of arbitrary or unjustifiable discrimination will be examined in the light of Article Xx's policy goals. ${ }^{71}$ In Brazil—Retreaded Tyres, Brazil exempted remolded tyres originating in MERCOSUR countries from the ban after a MERCOSUR tribunal found that Brazil's import ban constituted a restriction on trade prohibited

\footnotetext{
67 Ibid.

68 Johannes Norpoth, Mysteries of the твт Agreement Resolved? Lessons to Learn for Climate Change Polices and Developing Country Exporters from Recent твт Disputes, 47 Journal of World Trade 3 (2013), at 594 .

69 wTo Appellate Body Report, Brazil-Measures Affecting Imports of Retreaded Tyres (Brazil—Retreated Tyres), WT/Ds332/AB/R, adopted 3 December 2007, paras. 225-6.

70 Ibid., para. 227.

71 Arwel Davies, Interpreting the Chapeau of GATT Article XX in Light of the "New" Approach in Brazil-Tyres, 43 Journal of World Trade (2009), at 519.
} 
under MERCOSUR. The AB dismissed the argument because it bears no relationship to the objective of human health protection pursued by the import ban and even goes against this objective. ${ }^{72}$

It is also well settled that discrimination can also be arbitrary or unjustifiable where alternative measures exist that would have avoided or at least diminished the discriminatory treatment (less restrictive alternative) and would enable the regulating Member to achieve its legitimate policy goals with the same degree of efficiency and efficacy. ${ }^{73}$ In Us-Gasoline, the AB found that the us could employ a couple of alternative measures to avoid the discrimination resulting from the application of different baseline establishment methods. ${ }^{74}$ The us cited administration difficulties and financial costs against the use of alternative measures. The AB found that they were not insurmountable difficulties. Precisely because of the failure on the part of the us to seek cooperation with the two foreign governments and to take into account the costs for foreign refiners, the Ав ruled that us different baseline establishment methods to domestic and foreign refiners constitute a means of arbitrary or unjustifiable discrimination.

In US - Shrimp, the AB found several aspects of the Us regulation constitute arbitrary or unjustifiable discrimination. For example, the actual application of the Us measure, in effect, requires other wTо Members to adopt essentially the same regulatory programs and enforcement practices without taking into account the different situations of other nations. Shrimp harvested using methods comparable in effectiveness to those employed in the us have been excluded from the us market solely because they have not been certified by the Us. In the view of the $A B$, the measure is difficult to reconcile with the declared policy objective of protecting and conserving sea turtles..$^{75}$ The AB also pointed out the successful Inter-American Convention provides convincing demonstration that an alternative course of action was reasonably open to the Us for securing the legitimate policy goal of its measure a course of action other than the unilateral and non-consensual procedures of the import prohibition. ${ }^{76}$

In the recent three твт cases the Aв followed the same approach as the chapeau of Article $\mathrm{xx}$ in determining whether the detrimental impact on imports

\footnotetext{
72 wTo Appellate Body Report, Brazil—Retreaded Tyres, para. 228.

73 Zhou, Regulatory Purpose, at 1120.

74 wто Appellate Body Report, United States-Standards for Reformulated and Conventional Gasoline, WT/DS2/R, adopted 20 May 1996, 28-29.

75 Wто Appellate Body Report, United States-Import Prohibition of Certain Shrimp and Shrimp Products, WT/DS58/AB/R, adopted 6 November 1998, para. 165.

76 Ibid., para. 171 .
} 
stems exclusively from a legitimate regulatory distinction. In its analysis, the $\mathrm{AB}$ is essentially scrutinizing the cause or the rationale of the regulatory distinction put forward by the defending party to explain its existence. At the same time, the $\mathrm{AB}$ examines whether alternative measures are available that would have avoided or at least diminished the discriminatory treatment (less restrictive alternative) and would enable the regulating Member to achieve its legitimate policy goals with the same degree of efficiency and efficacy. In USClove Cigarettes, the us argues that the regulatory distinction between menthol cigarettes and clove cigarettes is necessary considering the impact on the us health care system associated with treating millions of menthol cigarettes smokers affected by withdrawal symptoms and the risk of development of a black market if menthol cigarettes are banned. However, the AB found that it was not clear if these risks would materialize if menthol cigarettes were to be banned, insofar as regular cigarettes would remain in the market. ${ }^{77} \mathrm{In}$ other words, the reasons given for the discrimination bear no rational connection to the regulatory objectives that the us government claimed to pursue. Also, the alternative measure such as a ban on menthol cigarettes would avoid the discriminatory treatment.

In US - Tuna, the us measure failed to address mortality arising from fishing methods other than setting on dolphins outside the ETP. As a result, the tuna caught in a non-ETP fishery would be eligible for the "dolphin-safe" label even if dolphins have in fact been killed or seriously injured. ${ }^{78}$ The regulatory distinction clearly cannot be reconciled with the regulatory objectives of dolphin conservation and provision of reliable information to consumers. The $A B$ also examined the Us assertion that alternative measures such as the appointment of an independent observer to monitor tuna-fishing are infeasible due to administrative and financial burdens. ${ }^{79}$ The AB dismissed the Us assertion and suggested that requesting a captain to monitor tuna-fishing activities and issue certificates could be a less restrictive alternative. Similarly, in US - Cool, the origin labelling program in operation fails to achieve the regulatory objectives they are designed to pursue. The lack of rational relationship between the origin labelling program and the regulatory objective constitutes an arbitrary and unjustifiable discrimination. ${ }^{80}$

Given the close relationship between the твт Agreement and the GATT 1994, including the similarities in their texts, the panels and the $\mathrm{AB}$ have

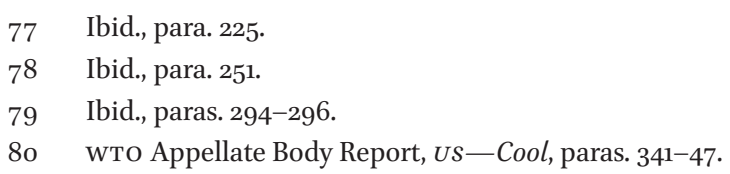


repeatedly found it useful, in examining the measure's consistency with the твт Agreement, to refer to the AB's guidance in previous disputes concerning the obligations under the GATT $1994 \cdot{ }^{81}$ In the three recent твт cases, the Ав has developed a clear-cut and consistent interpretation of the NT obligation embodied in Article 2.1. In particular, the interpretation of "like products" has adopted the same competition-oriented approach as "like products" in Article III:4 of the GATT 1994. It is a determination about the nature and extent of a competitive relationship between and among products at issue. ${ }^{82}$

By contrast, compared to Article III:4 of the GATT 1994, the Ав has adopted a different approach in interpreting "less favorable treatment" in Article 2.1 of the твт Agreement. Under Article III:4, the "less favorable treatment" represents a modification of the conditions of competition in the market place to the detriment of the group of imported products vis-à-vis the group of domestic like products. It is controversial how and to what extent Article III:1 informs the interpretation of less favorable treatment in Article III:4. In Article 2.1 of the твт Agreement, similar to Article III:4, a panel must first find that the measure at issue modifies the conditions of competition in the relevant market to the detriment of the group of imported products vis-à-vis the group of domestic like products. Different from Article III:4, the Ав made it clear that the existence of such a detrimental effect is not sufficient to demonstrate less favorable treatment. A panel must further analyze whether the detrimental impact on imports stems exclusively from a legitimate regulatory distinction. ${ }^{83}$ In examining whether the regulatory distinction is "legitimate", the $\mathrm{AB}$ has adopted an interpretative approach similar to the determination of arbitrary or unjustifiable discrimination in Article XX of the GATT 1994. It seems safe to conclude that the NT obligation in Article 2.1 of the твт Agreement is largely an integration of Article III:4 and the chapeau of Article XX of the GATT 1994.

Arguably, Article 2.1 of the твт Agreement helps to reduce the pro-trade bias embedded in the GATT $1994 .{ }^{84}$ Under the GATT 1994, Article XX is structured as "a general exception" even if they are designed to protect some legitimate public policies. If a non-fiscal internal measure is challenged, it will be scrutinized under Article III.4 first. Only after the measure is found in violation

81 wто Appellate Body Report, us - Clove Cigarettes, para. 10o; wTo Panel Report, European Communities- Measuring Prohibiting the Importation and Marketing of Seal Products (Ec-Seal Products), WT/DS400/R, para. 7.258.

82 WTo Appellate Body Report, us-Clove Cigarettes, para. 120.

83 Ibid., para. 182.

84 Ming Du, Domestic Regulatory Autonomy under the твт Agreement: From NonDiscrimination to Harmonization, 6 Chinese Journal of International Law 2 (2007), at 280. 
of Article III:4 will legitimate non-economic regulatory objectives be considered. This structure reflects a "hierarchy" between substantive trade obligations and domestic regulation priorities as legitimate regulatory objectives are subordinated as exceptions. ${ }^{85}$ This "obligation-exception" dichotomy tends in the first place to take a very suspicious attitude towards domestic regulatory measures. Even worse, the exceptions under Article xx are interpreted stringently. Consequently, this approach is criticized as likely to lead to a WTO Member losing or sacrificing its own regulatory autonomy in various areas of social policies solely for efficient resource allocation at the global level. ${ }^{86}$

Under the твт Agreement, there is no such dichotomy. Legitimate regulatory objectives are not given an inferior status as "exceptions" to a general free trade obligation. Instead, Article 2.1 overcomes the pro-trade bias in the GATT 1994 by elevating such exceptional social values to the status of inherent rights of wTO Members. This unitary structure means that trade and non-trade values will be considered at the same time. If the regulatory distinction is legitimate, i.e., there is a rational relationship between the regulatory distinction and the regulatory objectives, there is no less favorable treatment and no violation of the NT obligation.

Of course, the significance of this structure difference should not be overstated. Besides the symbolic abandon of the "obligation-exception" dichotomy, the principle implication of this structure difference for the wто jurisprudence is the allocation of burden of proof in practice. Under the GATT 1994, Article $\mathrm{XX}$ is an affirmative defence, with both the burdens of persuasion and proof on the defendant. In the context of Article 2.1 of the твт Agreement, the complainant must prove its claim by showing that the treatment accorded to imported products is less favorable than that accorded to like domestic products. ${ }^{87}$

The $E c$-Seal Products Case and the Future of NT Obligation in GATT 1994

As can be seen in Part II of this article, prior to $E C$-Seal Products, the AB was rather vague on the role of regulatory purpose in Article III:1 in interpreting the

85 See McRae, GATT Article XX, at 236.

86 Cho Sunjoon, Free Trade and Social Regulation: A Reform Agenda of the Global Trading System-Toward a New International Economic Law (London and New York: Kluwer Law International, 2003), at 36.

87 WTo Appellate Body Report, Us - Tuna II, para. 216. 
NT obligation. In the landmark EC-Seal Products case, the Aв finally unveiled its position in an unequivocal manner. In this case, the EU argued that for the purpose of establishing a violation of Article III:4, a finding that a measure has a detrimental impact on competitive opportunities for imported products, compared to like domestic products, is not dispositive. The EU submitted that a panel must conduct an additional inquiry into whether the detrimental impact on competitive opportunities for like imported products stems exclusively from a legitimate regulatory distinction. ${ }^{88}$ In essence, the EU requested the $\mathrm{AB}$ to transpose the legal standard for the non-discrimination obligations under Article 2.1 of the твт Agreement to Article III:4 of the GATT 1994. Such an analysis of "treatment no less favorable" goes beyond a consideration of the detrimental effect of a measure on the competitive opportunities for like imported products, and necessarily involves a consideration of possible policy rationale for such detrimental effect on trade.

The EU's arguments represent a rather popular view among WTO commentators. ${ }^{89}$ From a regulatory perspective, the EU's position is rather appealing. Article 2.1 of the твT and Article III:4 of the GATT 1994 overlap in their scope of application in respect of technical regulations. The NT obligations in both provisions are built around the same core terms "like products" and "treatment no less favorable". ${ }^{90}$ The твт Agreement and the GAтт 1994 also share the same objective and purpose: to strike a balance between trade liberalization and regulatory autonomy. ${ }^{91}$ One uniform approach to "treatment no less favorable" will not only clarify the scope of NT principle in the WTO law, but also help to make the case law more coherent across wTo Agreements with regard to domestic regulations including product standards.

However, the Ав decisively rejected the EU's position. Rather surprisingly, the $\mathrm{AB}$ took a strict textual approach to solve the long-standing controversy over the role of regulatory purpose in interpreting the NT obligation. Since Article III:4 does not explicitly refer to Article III:1, the AB considered that this omission of a textual reference to Article III:1 must be given meaning. ${ }^{92}$ Then the Aв held that Article III:4 is, itself, an expression of the principle set

88 WTO Appellate Body Report, Ec-Seal Products, para. 5.100.

89 Meredith A. Crowley and Robert Howse, "Tuna-Dolphin II: A Legal and Economic Analysis of the Appellate Body Report," 13 World Trade Review 2 (2014), at 332. See generally Gaetan Verhoosel, National Treatment and wTo Dispute Settlement: Adjudicating the Boundaries of Regulatory Autonomy (Oxford: Hart Publishing, 2002), 51-106. Wто Appellate Body Report, us-Clove Cigarettes, para. 100.

$91 \quad$ Ibid., paras. 92-96.

92 wTo Appellate Body Report, Ec—Seal Products, para. 5.115. 
forth in Article III:1. Consequently, if there is "less favorable treatment" of the group of like imported products, there is, conversely, protection of the group of like domestic products. In other words, the AB in EC-Seal Products supports the position that "less favorable treatment" is equal to a detrimental impact on competitive opportunities for imported products. There is no need to consider the regulatory purpose of the measure in Article III:1 and a finding of a detrimental impact will automatically send the measure to be justified under Article Xx. ${ }^{93}$

The AB's interpretation of "treatment no less favorable" reminds the readers of its position in $E C$-Bananas III in 1997. Admittedly, it has the advantage of a clear division of labor between Article III:4 and Article XX. Though both the твт and the GATT 1994 share the need to strike a delicate balance between the pursuit of trade liberalization and member states' right to regulate, this balance is expressed in different ways. In the GATT 1994, this balance is expressed by the NT obligation in Article III:4 as qualified by the general exception clause in Article XX in the GATT 1994. The AB in EC-Seal Products made it clear only the trade impact of the contested measure will be considered under Article III:4. Any possible legitimate policy justifications for the detrimental trade impact, which delineate the scope of a Member's right to regulate, will be considered under Article xx only. After Ec-Seal Products, the long-standing controversy on whether Article III affords policy space for a Member to consider Article Xx-like policy justifications is over.

Indeed, the major difficulty with the EU's position is that it is likely to disrupt the delicate balance between Article III and Article XX and risk rendering Article Xx inutile. Like it or not, the wTo Members agreed to a rules-exception structure in the GATT 1994. All non-economic policy justifications are supposed to be considered under Article xx. Admittedly, under Article 2.1 of the твт Agreement, the second step of this analysis is almost identical to the chapeau test of Article Xx. However, bearing in mind the contextual discrepancies between Article III:4 of the GATT 1994 and Article 2.1 of the TBT, it is challenging to introduce the concepts such as legitimate regulation distinction and even-handedness in Article 2.1 of the твт to article III:4, nor is it possible to consider fully all possible non-protectionist policy justifications under Article III:1.

However, the AB's interpretation of "treatment no less favorable" in $E C$-Seal Products is not free from doubts. First, the drafting record of the

93 WJ Davey and KE Maskus, Thailand-Cigarettes (Philippines): A More Serious Role for the "Less Favourable Treatment" Standard of Article III:4, 12 World Trade Review 2 (2013), at 178 . 
GATT NT obligation suggests that the specific intention of incorporating Article III:1 was to mandate purpose inquiries in dealing with origin-neutral measure under Articles III:2 and III:4. ${ }^{94}$ The AB's approach denies any possibility for the panel to undertake an analysis of the regulatory purpose when determining "treatment no less favorable". Second, the AB's interpretation of less favorable treatment may create inconsistent rulings between the GATT 1994 and the твт Agreement in the future. Article XX provides a closed list of legitimate objectives for government intervention. ${ }^{95}$ By contrast, under Article 2.1 of the твт Agreement, the list of possible legitimate objectives that may factor into an analysis is open. Thus, a technical regulation that has a detrimental impact on imports would be permitted if such detrimental stems from a legitimate regulatory distinction, while, under Article III:4 of the GATT 1994, the same technical regulation would be prohibited if the objective that it pursues does not fall within the subparagraphs of Article xx. ${ }^{96}$ Therefore, if Wто panels were to confine purpose inquiries to Article $\mathrm{xx}$, then the policy space that members want to retain with regard to the use of domestic measures in GATT 1994 may be severely restricted and the legitimacy of the multilateral trading system may be undermined..$^{97}$

Clearly, the Ав did not share such concerns. ${ }^{98}$ The Ав emphasized that the balance between trade liberalization and Members' right to regulate in the твт Agreement is not, in principle, different from the balance set out in the GATT $1994 .{ }^{99}$ If so, then the fact that this balance is expressed in different forms in different Agreement should not result in inconsistent rulings. This may imply that the $\mathrm{AB}$ may interpretation the legitimate regulatory objectives in the subparagraphs of Article XX more liberally in future disputes. The AB's expansive interpretation of "public morals" in Article xx(a) is an example in point. 100

The full implication of the AB's ruling remains to be seen. The $A B$ seems to have imposed a "strict liability" on importing countries. As Howse pointed

94 See Zhou, Towards Consistency, at 100-102.

95 F. Roessler, Beyond the Ostensible: A Tribute to Professor Robert Hudec's Insights on the Determination of the Likeness of Products under the National Treatment Provisions of the General Agreement on Tariffs and Trade, 37 Journal of World Trade 4 (2003), at 777.

96 wTo Appellate Body Report, Ec—Seal Products, para. 5.118.

97 Gene M. Grossman, Henrik Horn and Petros C. Mavroidis, Legal and Economic Principles of World Trade Law: National Treatment, IFN Working Paper No. 917 (2012), at 129.

98 WTo Appellate Body Report, Ec —Seal Products, paras. 5.128-5.129.

99 Ibid., para. 5.127.

100 Joost Pauwelyn, “The Public Morals Exception after Seals- How to Keep it under Check?" http://worldtradelaw.typepad.com/ielpblog/2014/05/the-public-morals-exception-afterseals-how-to-keep-it-in-check.html (accessed on 27 May 2014). 
out, very few legislative or regulatory distinctions between products would not fail this test. National safety, environmental and health rules, for example, are quite likely to have a different impact on goods manufactured in different places. The logical implication is that a large universe of laws and regulations is now prima facie illegal under wTо law. The outcome seems extreme and hard to reconcile with the intent and text of the GATT. ${ }^{101}$

To be fair, there are still a few possible "buffers" in Article III:4 after the AB decision in $E C$-Seal Products. Interpreted properly, these buffers may suggest some regulatory space for innocent regulations to pass muster under Article III:4. The first one is the AB's interpretation of the "genuine relationship" requirement between the measure at issue and its adverse impact on competitive opportunities for imported versus like domestic products.

To be clear, after EC-Seal Products, there is still room to argue that even if the measure at issue has a disparate impact on imported products compared to like domestic products, there is no "less favorable treatment". The key argument will be that a "genuine relationship" between the measure and the disparate impact on competitive opportunities does not exist. In ThailandCigarettes, the $\mathrm{AB}$ requires that in every case such a genuine relationship must exist. ${ }^{102}$ A genuine relationship means that it is the governmental measure at issue that affects the conditions under which like products, domestic and imported, compete in the market within a Member's territory. ${ }^{103}$ In Dominican Republic-Cigarettes, a fixed expense, such as the annual fee for the bond, leads necessarily to different per-unit costs among supplier firms, to the extent that these firms have different volumes of production or volumes of sales. ${ }^{104}$ Because imported cigarettes have a smaller market share, per unit costs of the bond requirement for imported cigarettes are higher than domestic cigarettes. The AB held that there was no "less favorable treatment" essentially because the disparate impact on imported products was not attributable to the measures at issue, but because of greater market shares of domestic cigarettes than those of imported cigarettes on the Dominican Republic market. In $E C$-Seal Products, the AB also identified a second possible scenario where the disparate market impact was caused not by the governmental measure but entirely by private choices. ${ }^{105}$ The "genuine relationship" requirement offers

\footnotetext{
101 Rob Howse, Joanna Langille and Katie Sykes, Sealing the Deal: the wTo Appellate Body's Report in EC-Seal Products, 18 (12) ASIL Insights, 4 June 2014.

102 Wто Appellate Body Report, Thailand -Cigarettes, para. 134.

103 WTo Appellate Body Report, Ec —Seal Products, para. 5.105.

104 WTо Appellate Body Report, Dominican Republic_Cigarettes, para. 98.

105 wто Appellate Body Report, Ec —Seal Products, para. 5.336.
} 
some room for a clearly non-protectionist measure with only incidental and negligible impact on imports to pass muster the "no less favorable treatment" test. In future trade disputes, whether there is a "genuine relationship" between the measure at issue and its adverse impact on competitive opportunities for imported versus like domestic products will be the main battlefield for the disputing parties.

The second issue is the role of "the design, structure and expected operations of the measures" in the "treatment no less favorable" analysis. In $E c$-Seal Products, the Ав explicitly denied the relevance of Article III:1 in interpreting "treatment no less favorable". Even so, there is lingering doubt on whether the $\mathrm{AB}$ has implicitly considered the regulatory purpose of the contested measure. This point could be observed from the AB's emphasis on examining "the design, structure and expected operations of the measure" when assessing whether the regulation at issue has modified the conditions of competition between imported and domestic like products under Article III:4. ${ }^{106}$ This is precisely the same approach that the $\mathrm{AB}$ has taken when assessing whether the dissimilar taxation of the directly competitive or substitutable imported and domestic products is applied "so as to afford protection" in the second sentence of Article III:2.107

The second sentence of Article III:2 specifies the NT obligation for internal taxation on directly competitive or substitutable products. It specifically refers to Article III:1. Article III:2 reads:

The [imported] products ... shall not be subject, directly or indirectly, to internal taxes or other internal charges of any kind in excess of those applied, directly or indirectly, to like domestic products. Moreover, no contracting party shall otherwise apply internal taxes or other internal charges to imported or domestic products in a manner contrary to the principles set forth in paragraph 1.

Article III:2, second sentence, has an Interpretative Note that reads:

A tax conforming to the requirements of the first sentence of paragraph 2 would be considered to be inconsistent with the provisions of the second

106 WTo Appellate Body Report, Thailand - Cigarettes, paras. 130 and 134.

107 Wто Appellate Body Report, Japan-Taxes on Alcoholic Beverages, WT/DS8/AB/R, WT/ DS10/AB/R, adopted 1 November, para. 116; WTo Appellate Body Report, PhilippinesTaxes on Distilled Spirits (Philippines-Distilled Spirits), WT/DS396/AB/R, adopted 20 January 2012, para. 190. 
sentence only in cases where competition was involved between...the taxed product and... a directly competitive or substitutable product which was not similarly taxed.

Therefore, to find violation of the second sentence of Article III:2, it must be established that the dissimilar taxation between the directly competitive or substitutable imported and like domestic products is applied "so as to afford protection". ${ }^{108}$ On how to establish this element, the AB noted:

We believe [it] requires a comprehensive and objective analysis of the structure and application of the measure in question on domestic as compared to imported products... Although it is true that the aim of a measure may not be easier ascertained, nevertheless its protective application can most often be ascertained from the design, the architecture, and the revealing structure of a measure. ${ }^{109}$

In Thailand-Cigarettes, the AB similarly mandated the panel to examine "the design, structure and expected operations" of the measure when assessing whether the regulation at issue has modified the conditions of competition between imported and domestic like products. ${ }^{110}$ By examining the same elements, the $\mathrm{AB}$ will be able to ascertain, even if implicitly, whether the measure in dispute is applied "so as to afford protection" for domestic production.

The AB's blunt rejection of the need to consider the possible policy rationale in Ec-Seal Products raises the question of the purpose of examining "the design, structure and expected operations" of the measure under Article III:4 in future disputes. One plausible interpretation may be that in Article III:4, the purpose of examining "the design, structure and expected operations" of the measure is to ascertain the disparate impact on imported products, whilst in the second sentence of Article III:2, the purpose is to ascertain the protectionist intent. But this is clearly an artificial distinction. In practice, a panel member will instinctively want to know if the measure has a bona fide regulatory purpose and to what extent its market effects are protective when they are called to decide whether the measure in question is in violation of Article III. ${ }^{111}$ Even though the Ав has explicitly denied the need to consider Article III:1 it was explicitly denied by the AB in Ec-Seal Products. Rather

\footnotetext{
108 Ibid.

109 WTo Appellate Body Report, Japan-Alcoholic Beverages II, para. 120.

110 WTо Appellate Body Report, Thailand_Cigarettes, paras. 130 and 134.

111 Hudec, Constraints on National Regulation, at 634-35.
} 
than being a separate step in Article III:2 analysis, it may be argued that the consideration of Article III:1 is subsumed within the "treatment less favourable" analysis. Many hope that in its future decisions the Ав might step back from its drastic decision to ignore all possible policy justifications under Article III:4 itself. ${ }^{112}$

\section{$5 \quad$ Conclusion}

As a pillar of international economic law, the NT obligation contributes significantly to the well-functioning and legitimacy of the world trading system. Unfortunately, the case law on the NT obligation has been long tainted by inconsistency and confusion. At the center of inconsistency lies the fundamental tension between the liberal devotion to free trade and the sovereign's right to tax, legislate, and regulate according to domestically determined policy. ${ }^{113}$

The recent твт jurisprudence on the NT obligation has rekindled Wто scholars' interests in exploring its implications for the interpretation of NT obligation in Article III:4 of the GATT 1994. On the one hand, the extensive cross-fertilization of case law between the GATT 1994 and the твт has provided some fresh evidence testifying the convergence of international trade law. ${ }^{114}$ On the other hand, the convergence is limited because it is difficult for WTо tribunals to overcome different textual and contextual structures among што Agreements and the well-established judicial precedents that have been built upon these distinct structures over the past sixty years. Despite serious efforts to bridge the gap, it seems that to achieve complete convergence on the NT obligation in the GATT/WTO law is not likely to happen in the short run. Like it or not, we have to live with the tale of interpreting the same NT obligation in divergent approaches in the GATT/WTO law in the foreseeable future.

\footnotetext{
112 Howse, Langille and Sykes, Sealing the Deal.

113 DiMascio and Pauwelyn, Nondiscrimination in Trade and Investment Treaties, at 59.

114 J.H.H. Weiler, Cain and Abel-Convergence and Divergence in International Trade Law, in J.H.H. Weiler (ed.), The EU, the WTO and the NAFTA: Towards a Common Law of International Trade (Oxford: Oxford University Press 2000), at 3-4.
} 